\title{
Evaluation of Physicochemical Properties and Sensory Attributes of Leavened Bread Produced from Composite Flours of Wheat (Triticum aestivum L.) and Sweet Potato (Ipomoea batatas L.)
}

\author{
Demelash Hailu Mitiku $^{1^{*}}$, Solomon Abera ${ }^{2}$ and Negussie Bussa ${ }^{2}$ \\ ${ }^{1}$ Department of Food Technology and Process Engineering, Wollega University, Shambu Campus, \\ P.O. Box: 38, Shambu, Ethiopia \\ ${ }^{2}$ Department of Food Science and Technology, School of Food Science, Postharvest Technology and \\ Process Engineering, Haramaya University, P.O. Box: 138, Haramaya, Ethiopia
}

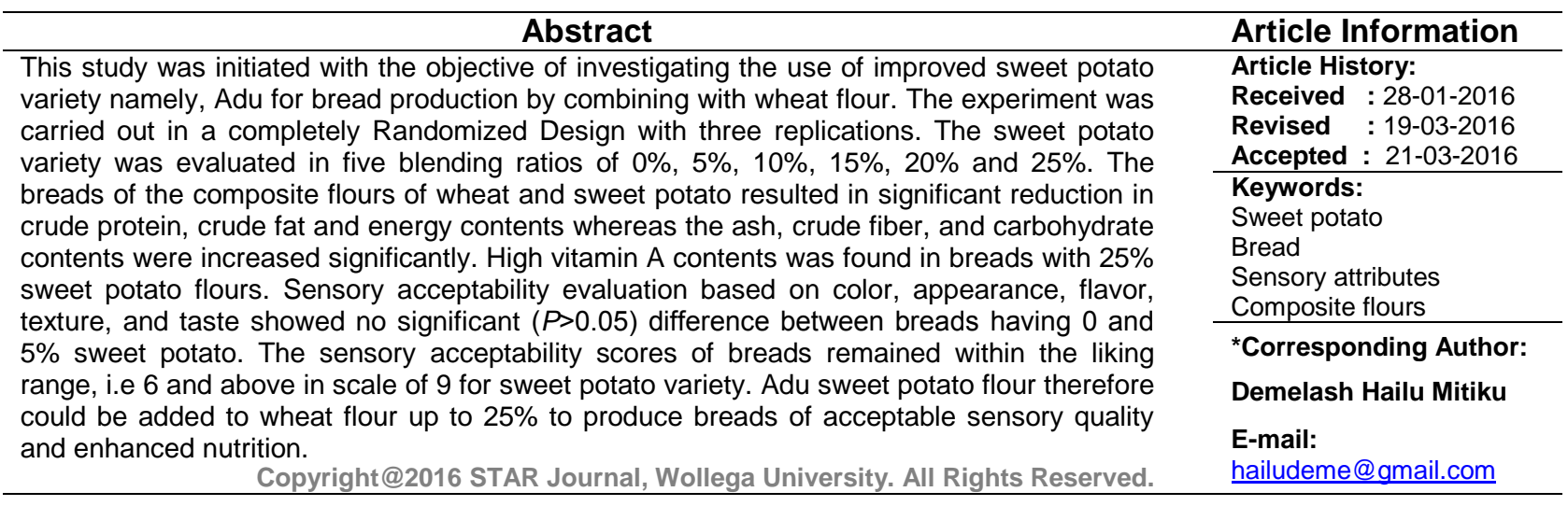

\section{INTRODUCTION}

Bread is made from the dough which is obtained from a mixture of flour, salt, sugar, yeast and water. It is a staple food for many people in the world. It is a good source of carbohydrates and micronutrients such as vitamins and minerals (Ebuehi et al., 2007). Bread is universally accepted as a convenient form of food that has desirability to all population. It is well accepted worldwide because of the low cost, ease of preparation, versatility, sensory attributes and nutritional properties. It also supplies irreplaceable nutrients for the human body in addition to being used as a significant source of energy and dietary fiber. It also provides protein, the B vitamins and minerals which are mostly magnesium, calcium and iron (Isserliyska et al., 2001).

Bread making is currently limited to wheat and a few other commonly used cereal seeds in many countries. Anjum et al. (2005) reported that wheat is the main ingredient in bread preparation being used as a dietary staple, averaging two-third of total consumption in the world which is responsible for formation of viscoelastic dough when hydrated with water, is capable of supporting gas cells and retaining gas. Yeast's is a leavening agent, strengthen and developing gluten in dough and contributing to the flavor generation in the bread and the most common one is Saccharomyces cerevisiae. The other ingredients which are used for bread production are salts, sugars and improvers.

Wheat (Triticum aestivum L.) is one of the important grain crops produced worldwide. According to the FAO, 2005 report, about 620 million metric tons of wheat was produced from 217 million hectares in the year 2005/06 with an average yield of 2.85 metric tons per hectare. It is grown on larger area than any other crop and its world trade is greater than for all other crops combined and it is easily stored and transported (Slafer and Satorre, 1999). Wheat is an important source of essential nutrients like carbohydrates, proteins, Vitamins B, iron, calcium, phosphorous, zinc, potassium and magnesium (Shewry et al.,1999). Wheat is used several ways in food: pasta, noodles, rolls, bread, biscuits, cakes, crackers, cookies, Steamed bread.

Wheat is one of the most important cereals cultivated in Ethiopia. It ranks fourth after teff (Eragrostis tef), maize (Zea mays) and sorghum (Sorghum bicolor) in area coverage and third in total production (CSA, 2007). The average per capital consumption of wheat in Ethiopia estimated to be $39 \mathrm{~kg} / \mathrm{year}$ during 1994-97. The amount of wheat imported to meet the national wheat requirements during 1995-97 was 331,000 tons (CIMMYT, 2000). The 


\section{Demelash Hailu Mitiku et al.,}

national average yield of wheat in the country, which is 1.379 tons $\mathrm{ha}^{-1}$, is $24 \%$ and $48 \%$ below the African and world average, respectively (FAO, 1994).

Partial substitution of wheat with sweet potato flour could be one way of producing bread with better nutritional quality and coupling with the daily increasing price of wheat in the world market. This is because of cheapen cost of sweet potato as compared with the wheat which is not affordable by large portion of the population. In addition, the use of sweet potato flour with other cereals like wheat for different food product development will be an opportunity to enhance the use the underutilized root crops like sweet potato with value addition and minimized postharvest loss.

Sweet potato has great economic importance, providing a supply of calories, vitamins and minerals in human nutrition. The root has carbohydrate content varying from 25 to $30 \%$, of which $98 \%$ easily digested. It has also excellent source of carotenoids, potassium, iron and calcium (Clark and Watson, 1998).

In Ethiopia, sweet potato is planted in altitudes between 800 and 1900 meters above sea level and grows below and above the minimum and maximum altitudes mentioned. Cooler temperatures, however, prolong the plant's vegetative cycle and tend to diminish yields (Doku, 1989). It has harvesting time, 3-8 months from planting, which is less than most other root and tuber crops (Woolfe, 1992). High levels of nutrition, and productivity and low levels of input have made sweet potato a valuable resource in the family garden. In particular, it can be a significant resource for families with low income (Villarreal and Griggs, 1982).

Sweet potato is used as high nutritional vegetable and industrial materials to process starch, noodle, bread, alcoholic beverage and many processed snack foods. In comparison to other major staple food crops, sweet potato has the following positive attributes: wide geographical production, adaptability to marginal conditions, short production cycle, high nutritional value and sensory versatility in terms of flesh colors, taste and texture.

Partial substitution of wheat by sweet potato in bread making can be used in order to improve the nutritional value of bread and reduction of dependence on wheat imports which will also lead to savings in foreign currency.

Therefore, research toward wheat bread product development that comprises sweet potato as component will address the nutrition deficiency challenges in wheat breads and postharvest loss minimization of sweet potato tubers. It will also contribute in the promotion of sweet potato production, increase farmer's income, create more jobs, reduce dependence and consequently the foreign exchange expended on wheat importation. These would add up to an improvement of food and livelihood security for the vast majority of the people. The objectives the research were to study the changes in nutritional quality and sensory acceptability of breads produced by adding different proportions of sweet potato flour to wheat flour, to characterize the physical properties of breads produced by mixing sweet potato with wheat flour at different proportions and to study the phytonutrient and mineral contents of the flours and breads.
Sci. Technol. Arts Res. J., Jan-March 2016, 5(1): 95-101

\section{MATERIALS AND METHODS}

\section{Experimental Materials}

The samples for investigation $35 \mathrm{~kg}$ of wheat flour which were prepared form 50:50 of imported red soft wheat (IRS) and white soft wheat (HAR 1685) was purchased from Dire Dawa food complex share company. Yeasts, salts and improvers were also obtained from Dire Dawa Food Complex Share Company. Sweet potato improved variety of Adu (cuba-2) of $30 \mathrm{~kg}$ was collected from Haramaya University Toni research farm, Dire Dawa. Wheat flour was stored in plastic bags and transported to Food Science and Postharvest Technology Laboratory.

\section{Sample Preparation}

\section{Production of Sweet Potato Flour}

The sweet potato tubers were thoroughly sorted to remove foreign materials from the lot. The sorted tubers were washed to remove adhering soil, dirt and extraneous materials. The tubers were peeled and sliced to facilitate fast rate of drying and ease milling operations. The sliced tubers were blanched in order to inactivate enzymes that may cause browning reaction and then cooled and drained followed by drying. The tubers were milled, sieved into fine flour and packaged for further use.

\section{Experimental Design}

The experiment was done in completely randomized design (CRD) with three replications of treatments. The improved variety of sweet potato, namely Adu, was tested under six blending ratios $(0,5,10,15,20$ and 25\%) for bread production. Wheat flour was used as control.

\section{Bread Preparation}

Breads were prepared by straight dough method bread production process (mixing and kneading, bulk fermentation, molding, rounding, intermediate proofing, molding, final proofing, baking, cooling and packaging). The flours were at a sweet potato: wheat mix ratios of $0: 100,5: 95,10: 90,15: 85,20: 80$ and $25: 75$ with first mix ratio being the control. The baking formula was $200 \mathrm{~g}$ of flour (wheat flour or the blend), $2 \mathrm{~g}$ yeast, $1 \mathrm{~g}$ bread improver, $2 \mathrm{~g}$ salt and $180 \mathrm{ml}$ water. All ingredients were mixed in a bowl manually and followed by adding water, kneading and shearing for 15 minutes until non-sticky homogeneous dough was formed. The dough was fermented in a bowl covered with polyethylene plastic in fermentation cabinet which was maintained at $27^{\circ} \mathrm{C}$ and $75 \%$ relative humidity for 60 minutes. After fermentation the doughs were taken out of the fermentation cabinet and remixed until its size was reduced almost to its original size. The dough was then kept back in the fermentation cabinet for second fermentation for 20 minutes. After that the dough was taken out, sheeted, scaled to $100 \mathrm{~g}$ dough pieces and molded. The dough proofed for 20 minutes and was placed on pan which was already greased by oil and baked in oven maintained at $200{ }^{\circ} \mathrm{C}$ for 15 minutes. Finally the bread were removed and cooled for 1 hour and packed in polyethylene bag and stored in a cool and dry area.

\section{Proximate Composition}

Nutritional composition of the composite bread samples, including moisture, crude fat, crude protein, crude fiber and total ash were determined using AOAC official methods of 925.09, 4.5.01, 979.09, 962.09, and 923.03, respectively (AOAC, 2000). Total carbohydrate was determined by difference. Results were expressed as 


\section{Demelash Hailu Mitiku et al.,}

$\mathrm{g} / 100 \mathrm{~g}$ of dry matter. Energy value was calculated using Atwater's conversion factors, where carbohydrates and proteins give $4 \mathrm{kcal} / \mathrm{g}$ while lipids give $9 \mathrm{kcal} / \mathrm{g}$.

\section{Minerals Analysis}

Iron, calcium and zinc were determined using atomic absorption spectrophotometer (AOAC, 2000, Model 200, and Germany).

\section{Phosphorous}

The phosphorus was determined calorimetrically by the method Fiske and Subbarow (1943).

\section{Total Carotenoids Content}

Total carotenoids content of sweet potato flour and bread samples were determined according Bandyopadhyay et al. (2008).

\section{Physical Parameters of Leavened Bread Loaf Weight}

Bread loaves were weighed 30 min after baking; using a laboratory scale and the readings were recorded in grams.

\section{Loaf Volume}

The loaf volume was determined by using rape seed displacement method (AACC, 2000, Standard 10-05). This was done by loading sugar into an empty box with calibrated mark until it reached the marked level and unloaded back again. The bread sample was put into the box and the measured sugar left outside the box was measured using measuring cylinder and recorded as loaf volume in $\mathrm{cm}^{3}$.

\section{Specific Volume}

Bread specific volume was calculated as loaf volume per unit weight of loaf $\left(\mathrm{cm}^{3} / \mathrm{g}\right)$ as follows.

$$
\text { Specific volume }\left(\mathrm{cm}^{3} / \mathrm{g}\right)=\frac{\text { Loaf volume }}{\text { Loaf weight }}
$$

\section{Sensory Evaluation}

The physical attributes of products, including the sensory characteristics such as color, aroma, consistency and texture are key measures of quality acceptability. Sensory evaluation of wheat-sweet potato bread samples were carried out according to the method described by Meilgaard et al (2007) by 30 panelists.

\section{Statistical Analysis}

Nutritional composition, Antinutritional factors, functional properties and sensory evaluation were statistically analyzed using the analysis of variance (ANOVA). The statistical package used was SAS version 9.1 software for windows (SAS ver, 2008). Statistical differences in samples were tested at $\mathrm{P} \leq 0.05$ and differences between means were compared using least significance difference (LSD). The results were expressed as mean $+\mathrm{SE}$.

\section{RESULTS AND DISCUSSION}

\section{Effect of Sweet Potatoes Flours on Proximate Composition}

The proximate compositions of breads produced with the different mix ratios of wheat and Adu sweet potato flours are presented in Table 1 . The values ranged from 4.20 to $7.43 \%$ for moisture, 1.35 to $3.07 \%$ for ash; 4.76 to $7.78 \%$ for protein, 1.27 to $2.2 \%$ for fat; 0.24 to $1.03 \%$ for fiber, 88.39 to $90.45 \%$ for carbohydrate and 389.9 to $404.60 \mathrm{kcal} / 100 \mathrm{~g}$ for energy.
Sci. Technol. Arts Res. J., Jan-March 2016, 5(1): 95-101

The highest (7.01\%) and lowest (4.2\%) moisture contents of composite bread produced from Adu sweet potato and wheat were observed from samples with $25 \%$ and $5 \%$ level of supplementation. There was significance $(P<0.05)$ difference in moisture content of whole wheat bread as compared to Adu sweet potato composite bread samples in almost all substitution levels. Moisture is a very important factor in the keeping quality of bread and high moisture can have an adverse effect on storage stability Madukwe et al. (2013).

The highest ash contents were recorded in 25\% level of substitution of Adu sweet potato composite breads with values of $3.07 \%$, whereas, the lowest were found in whole wheat bread samples with value of $1.35 \%$. Results showed that the ash contents of whole wheat bread were significantly $(P \leq 0.05)$ different from Adu composite bread samples with different supplementation levels. This finding was in agreement with the work of Aniedu and Agugo, (2010) who reported that the ash content increased with progressive increase in supplementation of sweet potato flour in wheat for bread production.

The highest protein content was found in whole wheat bread with value of $7.78 \%$ and lowest were recorded in composite breads having $25 \%$ sweet potato with values of $4.76 \%$ for that with Adu sweet potato. The protein content decreased as percentage of sweet potato flours increased. This may have been due to the low protein content of the sweet potato flours which resulted in reducing the protein level of the mixed flour as its proportion increased. This is similar to the earlier findings where protein contents of snacks reduced with supplementation of bread fruit flour with starch based products (Olaoye et al., 2007).

The fat contents of bread made with addition of flours of Adu sweet potato ranged from 1.24 to $2.2 \%$ respectively. They were significantly $(P \leq 0.05)$ lower than those of the whole wheat bread samples. This result showed that fat content of the breads of the composite flours decreased as the proportion of sweet potato flours increased. This is due to low level of fat in sweet potato flours and this could be an indication that the occurrence of oxidative rancidity might be reduced in the composite breads. This result is in agreement with the work of Idowu et al. (1996) who stated that the nutritional qualities decreased as the level of starchy staples increased.

The result of crude fiber obtained in Adu sweet potato supplemented bread samples were higher than those of pure wheat bread samples, implying that addition of sweet potato flour increases crude fiber. The highest values were recorded in 25\% supplementation level of Adu sweet potato flours with $1.03 \%$. The fiber contents of the composite breads made by adding flours of sweet potato variety exhibited significant $(P \leq 0.05)$ difference from that of the pure wheat breads. The crude fiber contents increased progressively with increased proportion of sweet potato flour. This increase in crude fiber content of the breads of the composite flours is the effect of the relatively higher percentage of crude fiber present in the sweet potato flours. The high level of dietary fiber is an indication in which it helps lowers the risk of constipation, colon and rectal cancer and the level of low density lipoprotein cholesterol in blood (Felicity and Maurica, 1992). 
Table 1: Effect of blending ratio of Adu sweet potato with wheat on proximate composition of bread on dry basis except moisture contents

\begin{tabular}{cccccccc}
\hline BR & Moisture (\%) & Ash (\%) & Protein (\%) & Fat (\%) & Fiber (\%) & Carbohydrate (\%) & Energy (kcal/100g) \\
\hline Bo & $5.71 \pm 0.01^{\mathrm{c}}$ & $1.35 \pm 0.01^{\mathrm{f}}$ & $7.78 \pm 0.08^{\mathrm{a}}$ & $2.20 \pm 0.03^{\mathrm{a}}$ & $0.24 \pm 0.01^{\mathrm{e}}$ & $88.51 \pm 0.12^{\mathrm{c}}$ & $404.60 \pm 0.14^{\mathrm{a}}$ \\
B1 & $4.20 \pm 0.01^{\mathrm{e}}$ & $2.09 \pm 0.01^{\mathrm{e}}$ & $7.67 \pm 0.35^{\mathrm{a}}$ & $1.49 \pm 0.01^{\mathrm{b}}$ & $0.25 \pm 0.02^{\mathrm{e}}$ & $88.39 \pm 0.32^{\mathrm{c}}$ & $398.15 \pm 0.05^{\mathrm{b}}$ \\
B2 & $4.31 \pm 0.13^{\text {ed }}$ & $2.35 \pm 0.10^{\mathrm{d}}$ & $6.32 \pm 0.15^{\mathrm{b}}$ & $1.38 \pm 0.01^{\mathrm{c}}$ & $0.36 \pm 0.01^{\mathrm{d}}$ & $89.70 \pm 0.17^{\mathrm{b}}$ & $396.54 \pm 0.01^{\mathrm{c}}$ \\
B3 & $4.50 \pm 0.08^{\mathrm{d}}$ & $2.45 \pm 0.05^{\mathrm{c}}$ & $5.51 \pm 0.07^{\mathrm{c}}$ & $1.24 \pm 0.02^{\mathrm{e}}$ & $0.48 \pm 0.00^{\mathrm{c}}$ & $90.45 \pm 0.07^{\mathrm{a}}$ & $395.42 \pm 0.21^{\mathrm{d}}$ \\
B4 & $7.43 \pm 0.15^{\mathrm{a}}$ & $2.72 \pm 0.04^{\mathrm{b}}$ & $5.01 \pm 0.18^{\mathrm{cd}}$ & $1.31 \pm 0.01^{\mathrm{d}}$ & $0.63 \pm 0.04^{\mathrm{b}}$ & $90.42 \pm 0.18^{\mathrm{a}}$ & $394.70 \pm 0.13^{\mathrm{e}}$ \\
B5 & $7.01 \pm 0.02^{\mathrm{b}}$ & $3.07 \pm 0.01^{\mathrm{a}}$ & $4.76 \pm 0.10^{\mathrm{d}}$ & $1.27 \pm 0.01^{\mathrm{de}}$ & $1.03 \pm 0.01^{\mathrm{a}}$ & $89.86 \pm 0.08^{\mathrm{b}}$ & $389.90 \pm 0.12^{\dagger}$ \\
\hline CV & $\mathbf{2 . 8 1}$ & $\mathbf{2 . 1 0}$ & $\mathbf{5 . 1 2}$ & $\mathbf{2 . 1 7}$ & $\mathbf{3 . 1 8}$ & $\mathbf{0 . 3 5}$ & $\mathbf{0 . 5 6}$ \\
LSD & $\mathbf{0 . 2 8}$ & $\mathbf{0 . 0 9}$ & $\mathbf{0 . 5 6}$ & $\mathbf{0 . 0 6}$ & $\mathbf{0 . 0 2}$ & $\mathbf{0 . 0 6}$ & $\mathbf{0 . 4 0}$ \\
\hline
\end{tabular}

$\mathrm{CV}=$ coefficient of variation, $\mathrm{LSD}=$ least significance difference, values are means \pm standard errors.

Means followed by the same letter in the column are not significantly different at $5 \%$ level of significance,
$\mathrm{BR}=$ Adu sweet potato blending ratios, Bo $=0 \%, \mathrm{~B} 1=5 \%, \mathrm{~B} 2=10 \%, \mathrm{~B} 3=15 \%, \mathrm{~B} 4=20 \%$ and $\mathrm{B} 5=25 \%$.

Regarding the carbohydrate contents of the breads made from the composite flours of wheat and sweet potato, significantly higher values were observed as compared to pure wheat breads. However, the differences among the composite breads are not significant for most samples and for those with significant differences no trend has been observed that relates to the proportions of the sweet potato flours added. Generally all the breads had very high carbohydrates of 88 to $90 \%$. The high level of carbohydrate is desirable in baked products because on heating starch granules in the presence of water, it swells and forms a gel which is important for the characteristic texture and structure of baked goods (Okorie and Onyeneke, 2012).

The energy contents of breads made from composite flours of wheat and sweet potato ranged from 389.9 to $404.6 \mathrm{kcal} / 100 \mathrm{~g}$, respectively, with significant $(P<0.05)$ differences among them. The energy content decreased with increase in proportion of the sweet potato flour. The lowest energy content was recorded for breads with $25 \%$ sweet potato of variety. The energy content of wheat bread was significantly $(P \leq 0.05)$ the highest as compared to those of wheat - sweet potato composite breads in all the level of supplementation. The difference in energy content could be due to variation in their protein, fat and carbohydrate contents (Giami et al., 2000).

\section{Mineral Composition of Bread Made of Adu Sweet Potato with Wheat Flour}

The mineral contents of bread samples produced from composite flours of wheat and Adu sweet potato are presented in Table 2. The iron contents of the breads increased with increase in the proportion of sweet potato flour added with significant $(P<0.05)$ differences among some of them and with whole wheat bread samples. The highest $(14.93 \mathrm{mg} / 100 \mathrm{~g})$ and lowest $(3.74 \mathrm{mg} / 100 \mathrm{~g})$ values of iron were recorded in the bread samples of 25 and $0 \%$ addition of sweet potato flours.

The zinc contents of the breads produced from flours having different proportion of Adu sweet potato exhibited significant $(P<0.05)$ differences among some of them; the highest $(3.05 \mathrm{mg} / 100 \mathrm{~g})$ being of bread samples with $25 \%$ sweet potato and lowest $(1.39 \mathrm{mg} / 100 \mathrm{~g})$ in whole wheat breads. As the proportion of sweet potato addition increased the zinc contents of the breads also increased.

Table 2: Effect of blending ratios of Adu sweet potato with wheat on mineral contents

\begin{tabular}{cccccc}
\hline BR & Fe (mg/100g) & Zn $(\mathbf{m g} / \mathbf{1 0 0 g})$ & $\mathbf{C a}(\mathbf{m g} / \mathbf{1 0 0 g})$ & $\mathbf{P}(\mathbf{m g} / \mathbf{1 0 0 g})$ & Vit. A $(\mathbf{m g} / \mathbf{1 0 0} \mathbf{g})$ \\
\hline B0 & $3.74 \pm 0.20^{\mathrm{d}}$ & $1.39 \pm 0.11^{\mathrm{d}}$ & $19.76 \pm 0.16^{\mathrm{a}}$ & $6.43 \pm 0.06^{\mathrm{e}}$ & $0.59 \pm 0.02^{\mathrm{d}}$ \\
B1 & $8.83 \pm 0.38^{\mathrm{c}}$ & $1.66 \pm 0.04^{\mathrm{c}}$ & $14.14 \pm 0.10^{\mathrm{b}}$ & $6.74 \pm 0.04^{\mathrm{d}}$ & $0.80 \pm 0.02^{\mathrm{c}}$ \\
B2 & $9.51 \pm 0.78^{\mathrm{c}}$ & $1.73 \pm 0.08^{\mathrm{c}}$ & $12.02 \pm 0.10^{\mathrm{c}}$ & $7.04 \pm 0.08^{\mathrm{d}}$ & $0.87 \pm 0.01^{\mathrm{c}}$ \\
B3 & $11.23 \pm 0.18^{\mathrm{b}}$ & $2.12 \pm 0.07^{\mathrm{b}}$ & $11.03 \pm 0.13^{\mathrm{d}}$ & $8.72 \pm 0.31^{\mathrm{c}}$ & $1.39 \pm 0.03^{\mathrm{b}}$ \\
B4 & $14.60 \pm 0.18^{\mathrm{a}}$ & $2.25 \pm 0.08^{\mathrm{b}}$ & $10.87 \pm 0.39^{\mathrm{d}}$ & $10.08 \pm 0.01^{\mathrm{b}}$ & $1.41 \pm 0.03^{\mathrm{b}}$ \\
B5 & $14.93 \pm 0.38^{\mathrm{a}}$ & $3.05 \pm 0.02^{\mathrm{a}}$ & $10.45 \pm 0.32^{\mathrm{d}}$ & $10.66 \pm 0.05^{\mathrm{a}}$ & $1.69 \pm 0.04^{\mathrm{a}}$ \\
\hline CV & $\mathbf{6 . 8 1}$ & $\mathbf{6 . 3 0}$ & $\mathbf{3 . 0 8}$ & $\mathbf{2 . 8 6}$ & $\mathbf{4 . 2 1}$ \\
LSD & $\mathbf{1 . 2 6}$ & $\mathbf{0 . 2 3}$ & $\mathbf{0 . 7 1}$ & $\mathbf{0 . 4 2}$ & $\mathbf{0 . 0 8}$ \\
\hline \multicolumn{5}{c}{ CV $=$ coefficient of variation, LSD = least significance difference, values are means \pm standard error. } \\
Means followed by the same letter in the column are not significantly different at 5\% level of significance. \\
BR = Adu sweet potato blending ratios; Bo = 0\%, B1 = 5\%, B2 = 10\%, B3 = 15\%, B4 = 20\% and B5 = 25\%.
\end{tabular}

The calcium contents of composite bread decreased with increase in the proportion of sweet potato added with significant $(P<0.05)$ differences with $(0,5,10$ and $15 \%)$ sweet potato added. No significance differences were observed between $(15,20$ and $25 \%)$ of sweet potato addition. The highest and lowest calcium content were observed in whole wheat breads $(19.76 \mathrm{mg} / 100 \mathrm{~g})$ and in $25 \%$ sweet potato addition $(10.45 \mathrm{mg} / 100 \mathrm{~g})$. Similar works are reported by Ifie (2011) on Madiga production from composite flour of wheat and sweet potato.

The phosphorous content ranged from $6.43 \mathrm{mg} / 100 \mathrm{~g}$ in whole wheat bread and $10.66 \mathrm{mg} / 100 \mathrm{~g}$ in $25 \%$ sweet potato flours added. There were significant $(P<0.05)$ differences among all the bread samples except in 5\% and $10 \%$ substitution of sweet potato flours in which no significance difference were observed.

The vitamin A contents were ranged from 0.59 $\mathrm{mg} / 100 \mathrm{~g}$ to $1.69 \mathrm{mg} / 100 \mathrm{~g}$ in the whole wheat and $25 \%$ addition of sweet potato bread samples, respectively. Vitamin A contents increased as the proportion of sweet potato added increases and were significantly $(P<0.05)$ different among some of them. Similar works have been reported by Ifie, (2011), in which the values ranged from 2.40 to $3.24 \mathrm{mg} / 100 \mathrm{~g}$. Vitamin $A$ is an essential nutrient 
Demelash Hailu Mitiku et al.,

required for maintaining immune function, playing an important role in hormonal antibody responses (Stephenson, 2001).

\section{Antinutritional Contents of Bread Produced from Adu Sweet Potato With Wheat Flour}

The antinutrient contents of bread samples produced from composite flours of wheat and Adu sweet potato are presented in Tables 3 . The tannin content increased with increase in the proportion of the sweet potato flour added with significant $(P<0.05)$ differences among all the breads including the whole wheat bread. This clearly indicated the impact of the sweet potato addition on the tannin content of the breads produced.

Table 3: Antinutrient composition of bread produced from Adu sweet potato and wheat flour

\begin{tabular}{ccc}
\hline BR & $\begin{array}{c}\text { Tannin } \\
(\mathbf{m g} / \mathbf{1 0 0 g})\end{array}$ & $\begin{array}{c}\text { Phytic acid } \\
(\mathbf{m g} / \mathbf{1 0 0 g})\end{array}$ \\
\hline B0 & $6.42 \pm 0.04^{\mathrm{e}}$ & $0.15 \pm 0.02^{\mathrm{e}}$ \\
B1 & $7.37 \pm 0.07^{\mathrm{d}}$ & $0.16 \pm 0.03^{\mathrm{d}}$ \\
B2 & $7.48 \pm 0.03^{\mathrm{d}}$ & $0.17 \pm 0.01^{\mathrm{d}}$ \\
B3 & $8.00 \pm 0.06^{\mathrm{c}}$ & $0.19 \pm 0.00^{\mathrm{c}}$ \\
B4 & $8.29 \pm 0.11^{\mathrm{b}}$ & $0.21 \pm 0.01^{\mathrm{b}}$ \\
B5 & $9.32 \pm 0.11^{\mathrm{a}}$ & $0.22 \pm 0.01^{\mathrm{a}}$ \\
\hline CV & $\mathbf{1 . 7 3}$ & $\mathbf{3 . 0 5}$ \\
LSD & $\mathbf{0 . 2 4}$ & $\mathbf{0 . 0 1}$
\end{tabular}

$\mathrm{CV}=$ coefficient of variation; LSD = least significance difference values are means \pm standard error. Means followed by the same letter are not significantly different at $5 \%$ level of significance; sweet potato blending ratio $(\mathrm{BR}): \mathrm{BO}=0 \%, \mathrm{~B} 1=5 \%, \mathrm{~B} 2=10 \%, \mathrm{~B} 3=15 \%$, $\mathrm{B} 4=20 \%$ and $\mathrm{B} 5=25 \%$.
Sci. Technol. Arts Res. J., Jan-March 2016, 5(1): 95-101

Similarly the phytic acid contents of the breads produced from flours having different proportion of sweet potato exhibited significant $(P<0.05)$ differences; the highest $(0.21$ and $0.22 \mathrm{mg} / 100 \mathrm{~g})$ being of samples with 20 and $25 \%$ sweet potato, with no statistical difference between them. The phytic acid content increased with increase in the level of the sweet potato in the composite flours.

\section{Physical Characteristics of Bread Samples}

The physical characteristics data of the breads produced from flours of wheat and Adu sweet potato which included loaf weight, loaf volume and specific volume were presented in Table 4 . The loaf weight values of breads produced with different proportions of sweet potatoes added exhibited significant $(P<0.05)$ differences among themselves and from that of whole wheat bread. The values ranged from 80.79 gram of the whole wheat bread to 94.05 gram of the bread with $25 \%$ sweet potato addition, with significant differences among them except between breads containing 5 and $10 \%$ sweet potato flour. The loaf weight increased with increase in sweet potato proportion. Shittu et al. (2007) reported the basic determinant of loaf weight to be the quantity of dough baked and moisture and carbondioxide diffused out of the loaf during baking. The increase in loaf weight could be attributed to increased moisture absorption and decreased air entrapment, resulting in heavy dough and thus heavy loaves (Horsfall et al., 2007).

Table 4: Effect of blending ratio of Adu sweet potato flour on the physical characteristics of the bread samples

\begin{tabular}{|c|c|c|c|}
\hline BR & Loaf Weight (g) & Loaf Volume $\left(\mathrm{cm}^{3}\right)$ & Specific Volume $\left(\mathrm{cm}^{3} / \mathrm{g}\right)$ \\
\hline $\mathrm{BO}$ & $80.79 \pm 0.38^{\mathrm{e}}$ & $340.79 \pm 0.38^{\mathrm{a}}$ & $4.22 \pm 0.02^{\mathrm{a}}$ \\
\hline B1 & $83.46 \pm 0.64^{d}$ & $330.46 \pm 0.30^{b}$ & $3.96 \pm 0.03^{b}$ \\
\hline B2 & $84.21 \pm 0.15^{d}$ & $324.66 \pm 0.76^{c}$ & $3.86 \pm 0.01^{\mathrm{c}}$ \\
\hline B3 & $87.96 \pm 0.14^{c}$ & $294.69 \pm 0.23^{d}$ & $3.35 \pm 0.01^{d}$ \\
\hline B4 & $90.14 \pm 0.54^{b}$ & $276.01 \pm 0.15^{\mathrm{e}}$ & $3.06 \pm 0.02^{\mathrm{e}}$ \\
\hline B5 & $94.05 \pm 0.15^{\mathrm{a}}$ & $249.35 \pm 0.36^{\dagger}$ & $2.65 \pm 0.01^{f}$ \\
\hline $\mathrm{CV}$ & 0.78 & 0.24 & 0.84 \\
\hline LSD & 1.20 & 1.27 & 0.05 \\
\hline
\end{tabular}

The data of the loaf volume, also presented in Table 4, showed significant $(P<0.05)$ difference among bread samples containing different proportions of sweet potato flour. The largest loaf volume was recorded for the whole wheat bread with value of $340.79 \mathrm{~cm}^{3}$. The rest of the breads had loaf volume progressively reducing as the percentage of the sweet potato flour increased, the lowest value $\left(249.35 \mathrm{~cm}^{3}\right)$ belonging to the bread with the largest percentage $(25 \%)$ of sweet potato. This could be attributed to the reduction in gluten content of the dough due to the reduced wheat percentage leading to less quantity and size of carbon dioxide bubbles forming in the interior of the bread. The gluten of the wheat flour is responsible for increased volume of the leavened wheat breads by trapping the carbondioxide gas generated in the dough and forming a network of bubbles of different sizes that give the porous spongy internal texture and large volume of breads. The loaf volumes are good indicators of the crumb, have light and airy the interior of the breads. Little values of loaf volume indicate a dense and compact crumb (Nwosu, 2014). This decrease in loaf volume with the addition of non-wheat flour to wheat flour has been reported to be associated with loaf volume depression, due to dilution effect on gluten content of composite flours (Dhingra and Jood, 2001).

The data of specific volume which also present in Table 4 , showed significant $(P<0.05)$ differences among the bread samples containing different proportion of sweet potato flours. The largest specific volume was recorded for the whole wheat bread with value of $4.22 \mathrm{~cm}^{3} / \mathrm{g}$. The rest of the breads had specific volumes progressively reducing as the percentage of the sweet potato flour increased, the lowest $\left(2.65 \mathrm{~cm}^{3} / \mathrm{g}\right)$ belonging to the bread with the largest percentage $(25 \%)$ of sweet potato. The cause for reduction of specific volume is the reduction in loaf volume and the increased in the loaf weight of bread with addition of sweet potato flour. It is the integral relationship of weight and volume of the loaf related to the rising power of the dough during baking (Ayo et al., 2008). 
Demelash Hailu Mitiku et al.,

Sensory Evaluation of Composite Breads of Sweet Potato and Wheat Flour

Sensory acceptability data of breads produced by blending wheat with Adu sweet potato are presented in Table 5. Color acceptability scores varied from 7.63 of the whole wheat bread in a 9-point scale to 6.32 of the bread containing $25 \%$ sweet potato, with significant $(P<0.05)$ difference among some of them. Breads containing 5 and $10 \%$ sweet potato obtained score of 7.53 and 7.43 with no significant difference $(P>0.05)$ between them and from that of the whole wheat bread. Breads with 20 and $25 \%$ sweet potato did not show statistical difference in color acceptability scores between them but had statistically the lowest value. All the scores indicated moderate to very much degrees of liking.

The acceptability scores of flavor, Table 5, of the same samples ranged from 7.27 of the whole wheat bread to
Sci. Technol. Arts Res. J., Jan-March 2016, 5(1): 95-101

6.53 of bread with $25 \%$ sweet potato. No significant difference $(P>0.05)$ was detected between the scores 7.10 and 7.02 of samples with 5 and $10 \%$ sweet potato, respectively, which are also statistically the same to the 7.27 of the whole wheat bread. Breads containing 15, 20 and $25 \%$ sweet potato, with lowest score of $6.77,6.70$ and 6.53 have no significant difference among them. These three values were significantly lower than that of the whole- wheat bread.

Texture acceptability scores ranged from 6.38 of the bread with $25 \%$ sweet potato to the 7.20 of the whole wheat bread, and had significant $(P<0.05)$ differences among some of them at $5 \%$ level. Breads with 0,5 and $10 \%$ sweet potato showed no significant difference among them and those with 15, 20 and $25 \%$ sweet potato did not show significant differences, either.

Table 5: Sensory mean score of bread produced from Adu sweet potato and wheat flour

\begin{tabular}{ccccccc}
\hline BR & Color & Appearance & Flavor & Texture & Taste & Over all acceptability \\
\hline B0 & $7.63 \pm 0.15^{\mathrm{a}}$ & $7.50 \pm 0.16^{\mathrm{a}}$ & $7.27 \pm 0.17^{\mathrm{a}}$ & $7.20 \pm 0.15^{\mathrm{a}}$ & $7.10 \pm 0.17^{\mathrm{a}}$ & $7.50 \pm 0.19^{\mathrm{a}}$ \\
B1 & $7.53 \pm 0.16^{\mathrm{a}}$ & $7.47 \pm 0.16^{\mathrm{ab}}$ & $7.10 \pm 0.17^{\mathrm{ab}}$ & $7.13 \pm 0.17^{\mathrm{a}}$ & $7.27 \pm 0.14^{\mathrm{a}}$ & $7.43 \pm 0.16^{\mathrm{a}}$ \\
B2 & $7.43 \pm 0.12^{\mathrm{a}}$ & $7.27 \pm 0.14^{\mathrm{b}}$ & $7.02 \pm 0.14^{\mathrm{ab}}$ & $6.90 \pm 0.14^{\mathrm{ab}}$ & $7.00 \pm 0.13^{\mathrm{ab}}$ & $7.27 \pm 0.14^{\mathrm{a}}$ \\
B3 & $6.80 \pm 0.13^{\mathrm{b}}$ & $6.87 \pm 0.14^{\mathrm{c}}$ & $6.77 \pm 0.14^{\mathrm{bc}}$ & $6.60 \pm 0.15^{\mathrm{bc}}$ & $6.68 \pm 0.15^{\mathrm{bc}}$ & $6.72 \pm 0.11^{\mathrm{b}}$ \\
B4 & $6.33 \pm 0.15^{\mathrm{c}}$ & $6.30 \pm 0.15^{\mathrm{d}}$ & $6.70 \pm 0.19^{\mathrm{bc}}$ & $6.53 \pm 0.18^{\mathrm{bc}}$ & $6.50 \pm 0.17^{\mathrm{c}}$ & $6.33 \pm 0.15^{\mathrm{bc}}$ \\
B5 & $6.32 \pm 0.16^{\mathrm{c}}$ & $5.77 \pm 0.16^{\mathrm{e}}$ & $6.53 \pm 0.18^{\mathrm{c}}$ & $6.38 \pm 0.22^{\mathrm{c}}$ & $6.10 \pm 0.16^{\mathrm{d}}$ & $6.10 \pm 0.16^{\mathrm{c}}$ \\
\hline CV & $\mathbf{1 0 . 1 3}$ & $\mathbf{6 . 2 8}$ & $\mathbf{1 2 . 6 4}$ & $\mathbf{1 3 . 0 8}$ & $\mathbf{1 1 . 5 4}$ & $\mathbf{1 1 . 7 3}$ \\
LSD & $\mathbf{0 . 3 6}$ & $\mathbf{0 . 2 2}$ & $\mathbf{0 . 4 4}$ & $\mathbf{0 . 4 5}$ & $\mathbf{0 . 4 0}$ & $\mathbf{0 . 4 1}$ \\
\hline \multicolumn{6}{c}{ CV = coefficient of variation, LSD = least significance difference. Values are means \pm standard error. } \\
\multicolumn{7}{c}{ Means followed by the same letter in a column are not significantly different at P $<0.05}$. \\
Where: BR = Adu sweet potato blending ratios; B0 = 0\%, B1 = 5\%, B2 = 10\%, B3 = 15\%, B4 = 20\%, B5 = 25\%.
\end{tabular}

The highest acceptability scores of Taste; $7.10,7.27$ and 7.00 belonged to breads having 0,5 and $10 \%$ sweet potato with no statistical difference among them. Statistically the lowest score at $(P<0.05)$ was 6.10 of bread having $25 \%$ sweet potato. This value is significantly $(P<0.05)$ lower than the 6.68 and 6.50 recorded for breads of 15 and $20 \%$ sweet potato with no difference between these two.

Generally, breads with 0,5 and $10 \%$ sweet potato showed no statistical difference among them in acceptability of all the sensory attributes while their scores were significantly higher than those of the breads with 15 , 20 and $25 \%$ sweet potato. This condition has been clearly depicted by the scores recorded for overall acceptability evaluation of the breads which are presented in the same table. These scores; $7.50,7.43$ and 7.27 for breads with 0,5 and $10 \%$ sweet potato had no statistical difference $(P$ $<0.05)$ among them but are significantly $(P<0.05)$ higher than those of the rest of the samples.

Generally the sensory acceptability scores of the breads produced from the composite flours wheat and Adu sweet potato remained above 6.00 in scale of 9 point which indicated the various degrees of liking. This can lead to a conclusion that Adu sweet potato can be used for production of breads of acceptable quality by blending, with wheat flour, up to $25 \%$. The higher ranking for wheat bread in all attributes could be due to the familiarization of the consumers to the normal wheat bread (Olaoye et al., 2006).

\section{CONCLUSIONS}

The present study was aimed at evaluating physicochemical properties and sensory acceptability of leavened bread produced from composite flours of wheat and sweet potato with the general objective of investigating the use of sweet potato flour for bread production in combination with wheat flour.

These finding produced bread of acceptable nutritional, functional and sensory qualities by adding $5 \%$ to $25 \%$ of sweet potato to wheat flour; showing new windows for further utilization of sweet potato.

The blending of wheat flour with sweet potato improved the mineral contents of breads, particularly the iron, zinc, phosphorous and vitamin A.

Based on the present study results, it can be recommendations that, research should be carried out to improve or increase research development activities on the storage, processing, preservation and quality of sweet potato products. Emphasis should be given to sweet potato based products as it helps to strengthen the economy of the nation and provide income to farmers. Furthermore, Microbial safety of the composite breads should be studied in future.

\section{Conflict of Interest}

None Declared. 
Demelash Hailu Mitiku et al.,

\section{REFERENCES}

AACC (2000). Approved Method of the American Association of Cereal Chemists, Inc., St. Paul, MN, USA.

Aniedu, C. and Agugo, U.A. 2010. Acceptability of bread produced from Hausa-potato and sweet potato composite flours. Journal of Agriculture and Social Research 10(2): 162-166.

Anjum, T., Bajwa, R. and Javaid, A. (2005). Biological Control of Parthenium I: Effect of Imperatacylindrica on distribution, germination and seedling growth of Parthenium hysterophorus L. International Journal of Agriculture and Biology 7(3): 448-450.

AOAC (2000). Association of official and analytical chemists, $15^{\text {th }} \mathrm{Ed}$ (Helrich, K.). Arlington, Virgina, USA.

Aremu, M.O., Olaofe, O., Akintayo, E.T. (2007). Functional properties of some Nigerian varieties of legume seed flours and flour concentration effect on foaming and gelation properties. Journal of Food Technology 5(2):109-115.

Ayo, J.A., Nkama, I. (2004). Effect of acha (Digitaria exiles) grain flour on the Physicochemical and sensory properties of bread. International Journal of Food Properties 7(3): 561-569.

Central Statistical Authority (2007). Agricultural sample survey: Report on area and production for major crops. Statistical Bulletin 388.Addis Ababa, Ethiopia.

Clark, C.A. and Watson, B. (1998). Susceptibility of weed species of convoulaceae to root infecting pathogens of sweet potato. Plant Diseases 67: 907.

Doku, E.V. (1989). Root crops in Ethiopia, In: M.N. Alvarez and S.K.Hahn (ed). Root Crops and Low Input Agriculture: Helping to meet food self-sufficiency goals in eastern and Southern Africa.

Ebuehi, O.A.T., Owolabi, O.O., Ikanone, C.E., Amabibi, I.T.T. and Ajekwu, A.P. (2007). Organoleptic, mineral and vitamin evaluation of some Nigerian bread. Nigerian Food Journal 25(2): 95-100.

FAO (Food and Agriculture Organization of the United Nations) (2005). FAOSTAT [Online]. Available at http://www.fao.org/faostat[cited 24 Feb. 2005; verified 14 Oct. 2005]

Felicity S.K and Ann B. 1992. Nutrition for developing countries. Second Edition. PP 11.

Fiske, C.H. and Subba Row, Y. (1943). The colorimetric determination of phosphorus. Journal of Biological Chemistry 66(2):375-400.

Giami, S.Y., Adindu, M.N., Akusu, M.O. and Emelike, J.N.T. (2000). Compositional, functional and storage properties of flour from raw and heat processed African bread fruit (Trecuia Africana decne). Plant Foods for Human Nutrition 55: 357-368.

Horsfall, D.M., Lucy, E., Nwaojigwa, S.U. (2007). Chemica composition, functional and baking properties of wheatplantain composite flours. African Journal of Food Agriculture and Nutrition 7: 1-23.
Sci. Technol. Arts Res. J., Jan-March 2016, 5(1): 95-101

Idowu, M.A., Oni, A. and Amusa, B.N. (1996). Bread and biscuit making potential of some Nigerian cocoyam cultivars. Nigerian of Food Journal 14: 1-12.

Ifie Idolo (2011). Sensory and nutritional Quality of Madiga produced from composite flour of wheat and sweet potato. Pakistan Journal of Nutrition 10(11): 1004-1007.

Isserliyska, D., Karadjov, G., Angelov, A. (2001). Mineral composition of Bulgarian wheat bread. European Food Research Technology 213: 244-245.

Madukwe E.U., Obizoba I.C, and Chukwuka O.F. (2013). Nutrient assessment of processed rice (Oryza sativa), soybean (Glycine max Merr) flours/groundnut (Arachis hypogea) paste and sensory attributes of their composites. International Journal of Scientific and Research Publications 3(8): 1-8.

Meilgaard, M.C., Civille, G.V., and Carr, B.T. (2007). Sensory Evaluation Techniques, $4^{\text {th }}$ Edition, CRC Press L.L.C., New York.

Nwosu Justina N., Owuamanam C.I., Omeire G.C. and Eke C.C. (2014). Quality parameters of bread produced from substitution of wheat flour with cassava flour using soybean as an improver. American Journal of Research Communication 2(3).

Okorie, S.U. and Onyeneke, E.N. (2012). Production and quality evaluation of baked cake from bled of sweet potatoes and wheat flour. International Journal of Natural and Applied Sciences 3(2).

Olaoye, O.A, Onilude A.A. and Idowe O.A. 2006. Quality Characteristics of Bread Produced from composite flours of wheat, plantain and soybeans. African Journal of Biotechnology 5(1): 102-1106.

Olaoye, O.A., Onilude, A.A. and Olaoye, C.O. (2007). Breadfruit flour in biscuit making. Journal of Food Science and Technology 20-23.

SAS, ver (2008). The statistical analysis system version SAS Inc. Carry.N.C. U.S.A

Shewry, P.R. (1999). The synthesis, processing, and deposition of gluten proteins in the developing wheat grain. Cereal Foods World 44: 587-589.

Shittu, T.A., Raji, A.O., Sanni, L.O. (2007). Bread from composite cassava-wheat flour I: Effect of baking time and temperature on some physical properties of bread loaf. Food Research International 40: 280-290.

Stephensen, C.B. (2001). Vitamin A, infection and immune function. Annual Reviews in Nutrition 21: 167-192.

Villarreal, R.L. and Griggs, T.D. (1982). Symposium overview. Sweet Potato. Pp1.

Woolfe, J.A. (1992). Sweet potato, an untapped food resource.Cambridge University Press, Cambridge, England, $643 \mathrm{pp}$. 